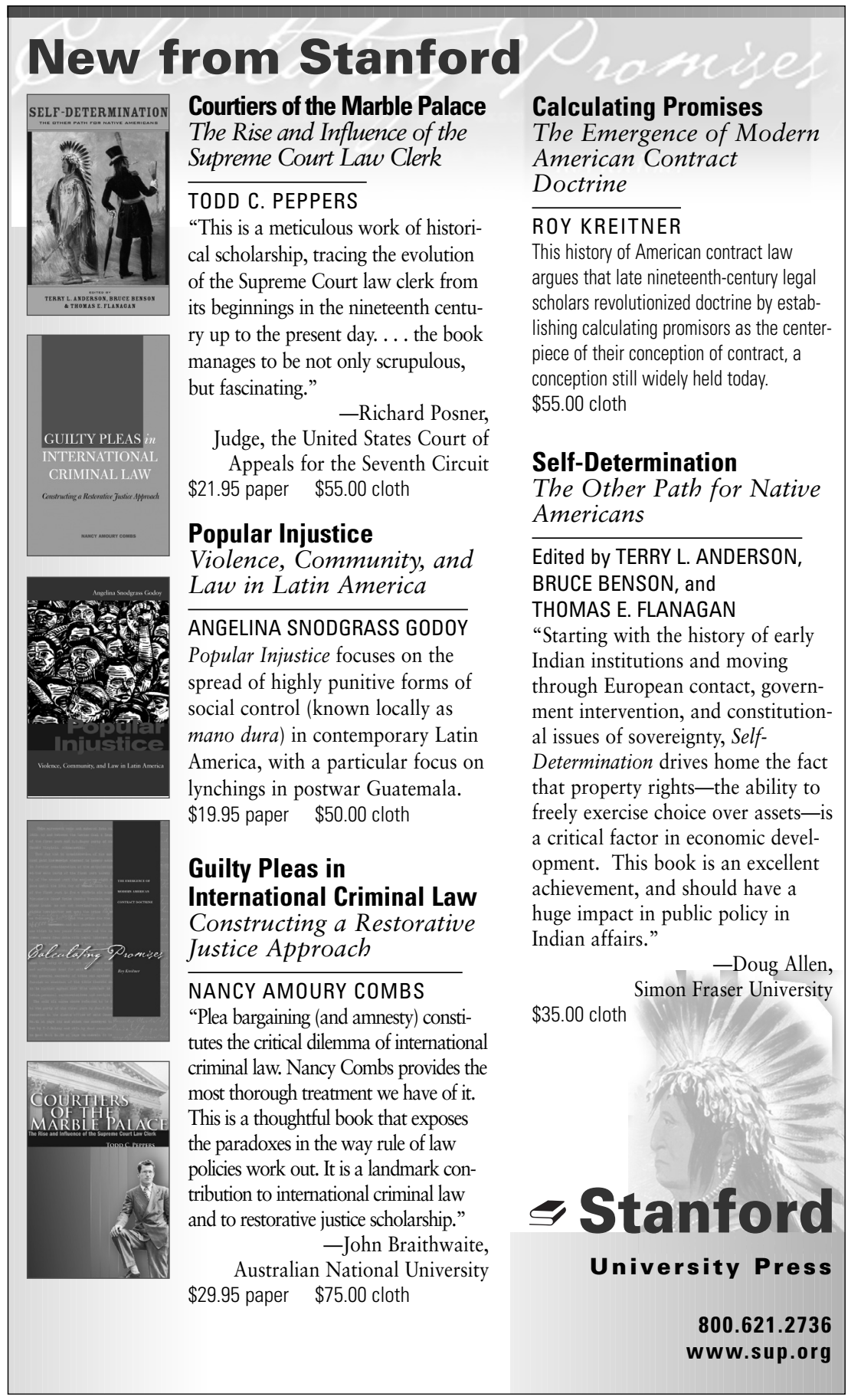




\section{COMETO ORDER.}

\section{Studies in the Legal History of the South}

Series editors: Paul Finkelman, Timothy S. Huebner, and the late Kermit L. Hall

Nerw in the series

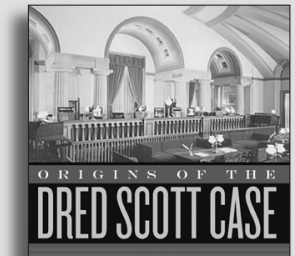

Origins of the Dred Scott Case

Jacksonian Jurisprudence and the

Supreme Court, 1837-1857

Austin Allen

$\$ 22.95 \mathrm{pb}, \$ 59.95 \mathrm{cl}$

"An original and provocative look at one of the most important judicial decisions in American history."

-Christopher Waldrep, author of The Many

Faces of Judge Lynch

New in paperback!

Double Character

Slavery and Mastery in the Antebellum

Southern Courtroom

Ariela J. Gross

$\$ 22.95 \mathrm{pb}$

"Moves the study of slave law beyond the traditional notion that the civil law of slavery concerned slaves only as property and not as people."

- Journal of American History

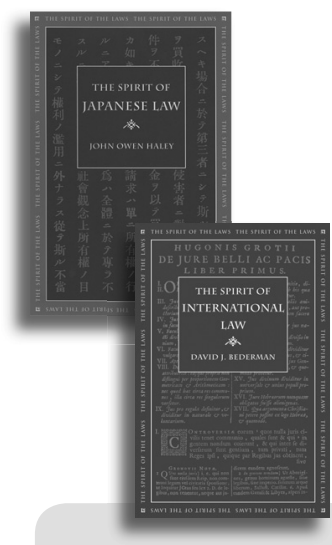

\section{Spirit of the Laws series}

Series editor: Alan Watson

Nerw in paperback

The Spirit of Japanese Law

John Owen Haley

$\$ 22.95 \mathrm{pb}$

The Spirit of International Law David J. Bederman $\$ 22.95 \mathrm{pb}$

The University of

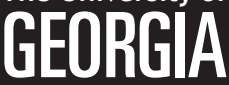

PRESS

1-800-266-5842

www.ugapress.org 


\section{John Millar's History of the English Government}

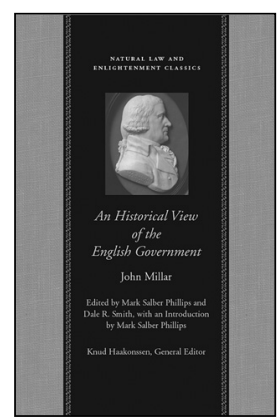

Published October 2006. $6 \times 9.918$ pages.

Hardcover ISBN 0-86597-444-6. $\$ 20.00 / £ 13.95$.

Paperback. ISBN 0-86597-445-4. $\$ 12.00 / £ 8.95$

\section{An Historical View of the English Government}

\author{
By John Millar
}

Edited by Mark Salber Phillips and Dale R. Smith, with an Introduction by Mark Salber Phillips

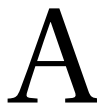

n Historical View of the English Government discusses three of the most substantive periods in English government and manners: from the Saxon settlement to the Norman Conquest, from the Norman Conquest to the accession of James I, and from James I to the Glorious Revolution. Through these three phases Millar traces the development of the "great outlines of the English constitution"- the history of institutions of English liberty from Saxon antiquity to the revolution settlement of 1689 .
For orders shipping
South, and Central
Liberty Fund, Inc. Order Dept. ALtR37

8335 Allison Pointe Trail, Suite 300 Indianapolis, IN 46250-1684

\section{For all other regions:}

\section{Gazelle Academic}

Tel: $\quad+44(0) 152468765$

Fax: $\quad+44(0) 152463232$

E-mail: $\quad$ sales@gazellebooks.co.uk 


\section{Military Tribunals and Presidential Power}

American Revolution to the War on Terrorism

\section{Louis Fisher}

"We are in Fisher's debt once again. His riveting account is at once authoritative and invaluable as a guide to the perplexing problem of coping with real and imagined terrorism in our time. Superb."

-Stanley Kutler, author of Abuse of Power 296 pages, Cloth $\$ 35.00$, Paper $\$ 16.95$

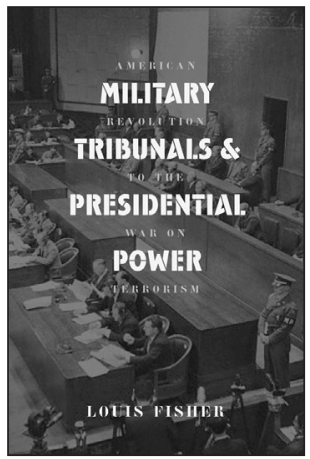

\section{To the Flag}

\section{The Unlikely History of the Pledge of Allegiance}

Richard J. Ellis

"Ellis deftly tells the story of America's fretful civic poem. Along the way we encounter socialism, race fears, ethnic antagonism, patriots, millenarianism, and bored school kids. Fine, thoughtful, and delightful."-James A. Morone, author of Hellfire Nation: The Politics of Sin in American History 312 pages, 12 photographs, Cloth $\$ 29.95$

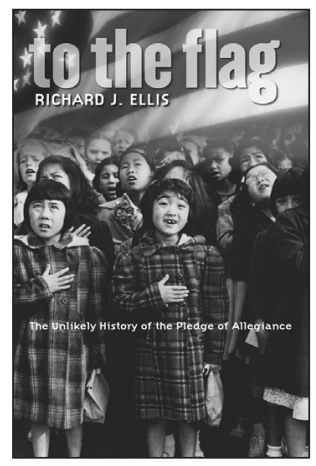

\section{Landmark Law Gases and American Society}

\section{Nazi Saboteurs on Trial}

A Military Tribunal and American Law Second Edition, Abridged and Updated Louis Fisher

"A well-written, timely history that belongs in all research, university, and general libraries.... Will inform policy debates ... on the scope of presidential power and the role of courts in protecting civil liberties."-American Historical Review 204 pages, Paper $\$ 15.95$

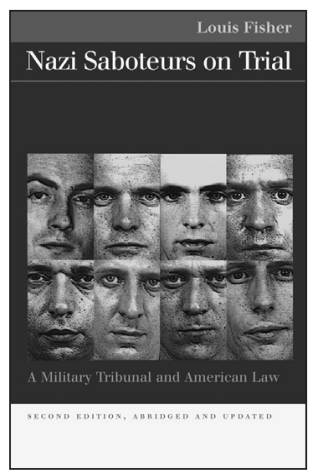




\section{Landmark Law Cases and American Society}

Peter Charles Hoffer and N.E.H. Hull, series editors

\section{Griswold v. Connecticut Birth Control and the Constitutional Right of Privacy}

John W. Johnson

"Demonstrates that the constitutionally protected right to privacy is only of recent vintage but has ramifications for American law and politics that are likely to last for many years." - Philippa Strum, author of When the Nazis Came to Skokie: Freedom for Speech We Hate

272 pages, Cloth $\$ 35.00$, Paper $\$ 15.95$

\section{The Times and Trials of Anne Hutchinson}

\section{Puritans Divided}

Michael P. Winship

"The single most comprehensive account of the oftenmisinterpreted trials of one of America's first great dissenters. Winship's unparalleled understanding of seventeenth-century New England Puritanism supplies a context too frequently missing from previous accounts."-Mary Beth Norton, author of In the Devil's Snare: The Salem Witchcraft Crisis of 1692 184 pages, Cloth $\$ 35.00$, Paper $\$ 14.95$

\section{The Confederacy on Trial} The Piracy and Sequestration Cases of 1861

Mark A. Weitz

"Illuminates long neglected aspects of the legal history of the Civil War." - Harold Hyman, author of A More Perfect Union: Constitutional Impacts of the Civil War and Reconstruction

224 pages, Cloth $\$ 35.00$, Paper $\$ 15.95$
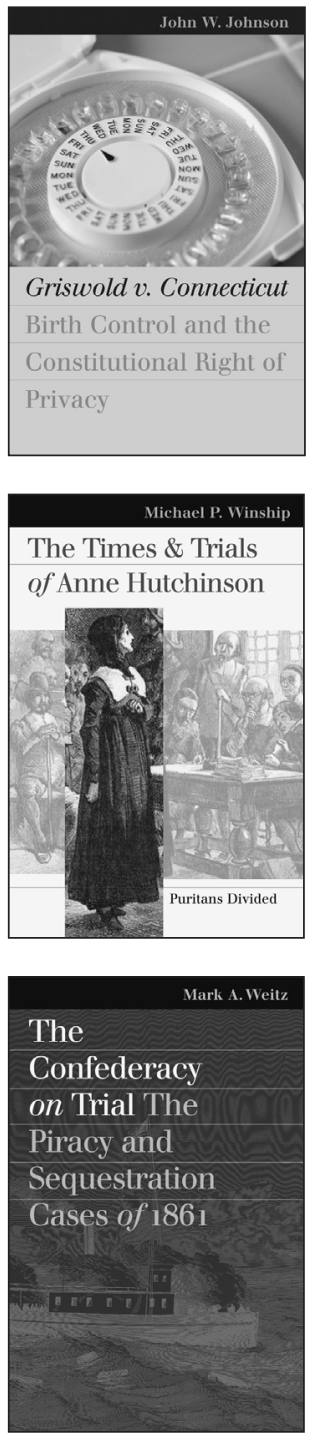

Available from bookstores or from the press.

VISA, MasterCard, and American Express accepted.

\section{University Press of Kansas}

785-864-4154 · Fax 785-864-4586 • www.kansaspress.ku.edu 


\section{Rationing Justice}

Poverty Lawyers and Poor People in the Deep South

\section{KRIS SHEPARD}

"Explores the provision of legal services to poor people in the South over a thirty-year period with special emphasis on Georgia, Alabama, and Mississippi. An important topic with broad ramifications for the political, social, and legal history of the South. A solid contribution to the literature concerning legal services to the poor as well as the literature dealing with the efficacy of litigation in accomplishing social change."

-Davison M. Douglas, author of Reading, Writing, and Race: The Desegregation of the Charlotte Schools

Making the Modern South • David Goldfield, Series Editor $\$ 55.00$

\section{Rationing Justice}

Poverty Laweryer and Poor People in the Dees South

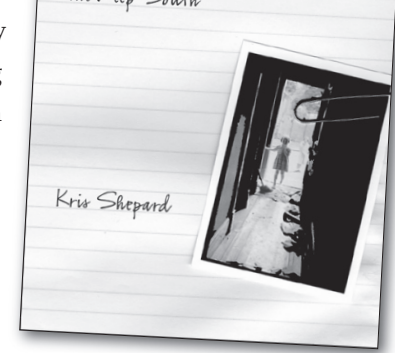

\section{9 \\ LOUISIANA STATE UNIVERSITY PRESS}

(800) 861-3477 • (800) 305-4416 FAX • Purchase our books at www.Isu.edu/lsupress • Shipping charges will apply 


\section{American Society for Legal History}

The American Society for Legal History is a nonprofit membership organization dedicated to fostering scholarship, teaching, and study concerning the law and institutions of all legal systems, both Anglo-American and international. Founded in 1956, the Society sponsors the journal and Studies in Legal History, a series of book-length monographs available to ASLH members at substantial prepublication discounts. In addition, the Society holds an annual meeting to promote scholarship and interaction among teachers, practitioners, and students interested in legal history, and publishes a semiannual newsletter reporting developments in the field. For further information concerning the Society, please write: William P. LaPiana, New York Law School, 57 Worth St., New York, New York 10013.

To become a member of the Society, please complete and mail the application to University of Illinois Press, 1325 S. Oak St., Champaign, IL 61820.

\section{Membership Application}

Please check appropriate membership below:

U.S. Member Non-U.S. Member

Regular Member, with an annual income

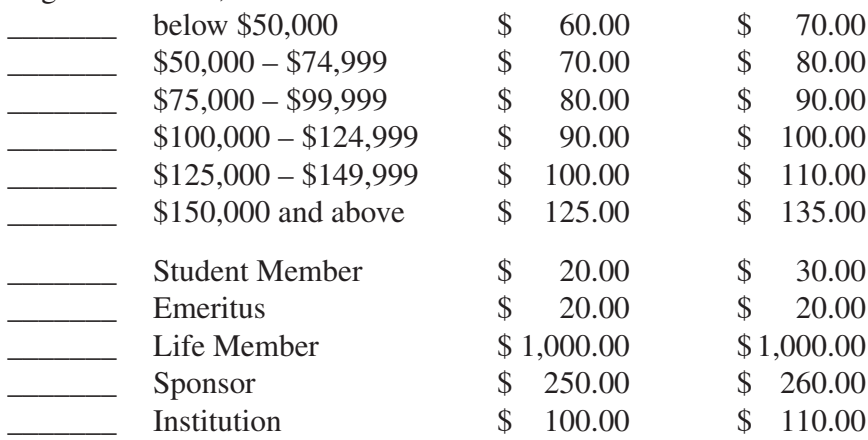

Please remit amount due in U.S. dollars drawn on a U.S. bank, payable to: University of Illinois Press.

Total Amt: \$ Visa/MC:

Acct. Name: Exp. Date:

Signed:

Name:

Institution:

Address:

City: State: Zip:

Phone (Home): (Office):

Fax: E-mail: 


\section{American Society for Legal History}

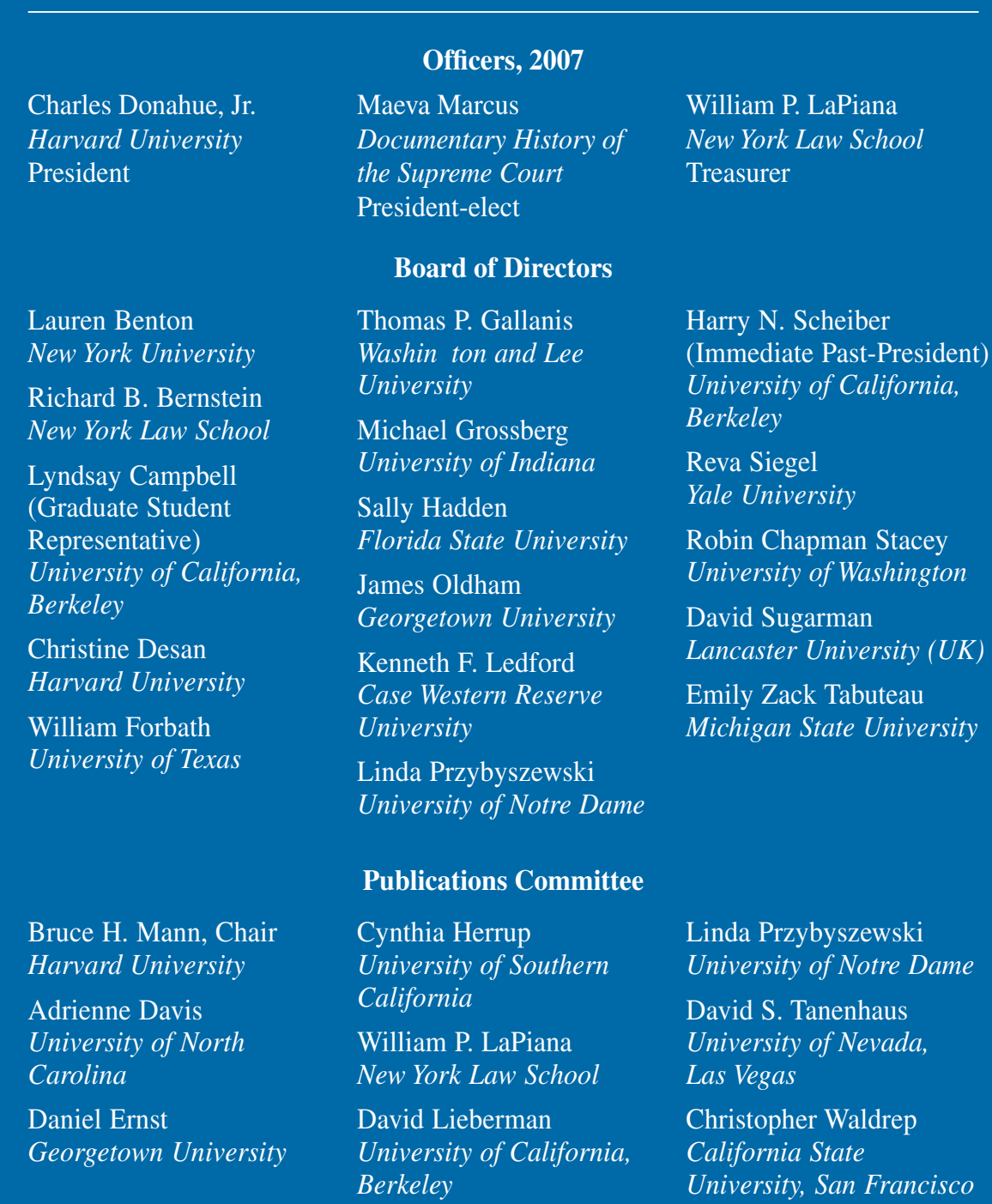

Fellows of the American Society for Legal History

$\begin{array}{lll}\text { Honorary Fellows } & \text { Morton J. Horwitz } & \text { John Phillip Reid } \\ \text { Morris S. Arnold } & \text { Harold M. Hyman } & \text { Harry N. Scheiber } \\ \text { Morris Cohen } & \text { Laura Kalman } & \text { A. W. B. Simpson } \\ \text { Lawrence M. Friedman } & \text { Stanley N. Katz } & \text { W. A. J. Watson } \\ \text { R. H. Helmholz } & \text { John T. Noonan, Jr. } & \\ \text { Corresponding Fellows } & \text { André Gouron } & \text { S. F. C. Milsom } \\ \text { J. H. Baker } & \text { Paolo Grossi } & \text { Kjell Modéer } \\ \text { Raoul C. Van Caenegem } & \text { Peter Landau } & \text { Peter G. Stein } \\ \text { Ennio Cortese } & \text { Anne Lefebvre-Teillard } & \text { Michael Stolleis } \\ \text { Robert Feenstra } & \text { Hector L. MacQueen } & \end{array}$

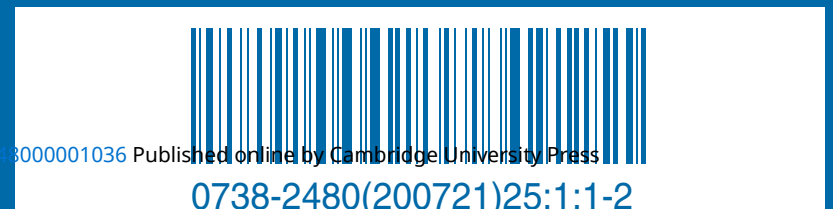

